\title{
A NOVEL FLC FOR PV ARRAYS CONNECTED TO THE UTILITY GRID
}

\author{
R.A.Amer, A.M.Afifi and G.A.Morsy \\ Electrical Engineering Department, Faculty of Engineering \\ Menoufiya University, Shebin El-Kom,Egypt
}

\begin{abstract}
This paper provides a suitable fuzzy logic control (FLC) system for three-phase grid-connected photovoltaic (PV) system which aims to work at unity power factor and constant output voltage suitable with the grid for any PV side or grid side disturbances. Also by the control system, the (PV-common DC link) interface transfers the energy drawn from the PV array by keeping dc voltage constant. Also, FLC results are compared with conventional (PI) control at the same disturbances. The model contains a detailed representation of the main components of the system that are the PV arrays, the booster converter and the grid side inverter. A novel method for Maximum Power Point Tracking (MPPT) technique through fuzzy logic system is implemented and compared with INC MPPT technique. MPPT techniques are obtained under different temperature values and irradiation levels. Modeling and control is carried out using MATLAB-SIMULINK. The simulation results showed the control performance and dynamic behavior of the system at various disturbances such as three-phase short circuit at connection point, one line outage and irradiation variations.

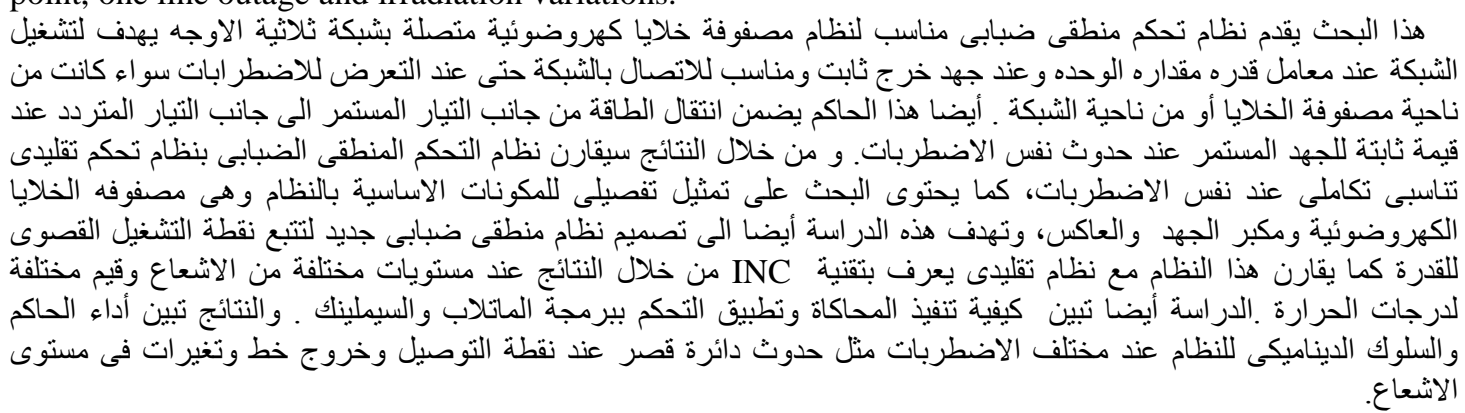

Keywords: PV arrays, Grid connected, MPPT, DC-DC boost converter, PI control, FLC.

\section{Introduction}

According to global warming, global surface temperatures have raised at a rate near $0.6 \mathrm{C} /$ century because of effluent gas emissions [1-2]. Also, the fossil fuel plants have environmental problems as air pollution, acid precipitation, ozone depletion, forest destruction, and radioactive emissions.

To reduce these problems, some solutions have studied including energy conservation through improved energy efficiency, a reduction in fossil fuel use and an increase in environmentally friendly energy supplies. Recently, energy generated from clean, efficient and environmentally friendly sources has become one of the major challenges for engineers and scientists. Among them, photovoltaic (PV) application has received a great attention in research because it appears to be one of the most efficient and effective solutions to this environmental problem [3-4].
The conventional stand-alone photovoltaic system has the advantages of simple system configuration and control scheme. However, in order to draw maximum power from PV arrays and store excess energy, battery banks are required in this system. For high power systems, they will increase system cost and weight, and narrow the application areas. Therefore, grid-connected systems, which are designed to relieve this shortcoming, have become the primary researches in PV power supply applications [5].

The solar cell produces a low amount of current and voltage. So, in order to meet a large load demand, the solar cells have to be connected into modules and the modules connected into arrays. The output voltage from PV arrays varies with solar radiation and ambient temperature. So in order to connect to the electrical grid, the output voltage from PV arrays should be fixed and converted to AC voltage which can be done by an inverter. 
The DC-DC converter and inverter have the task to implement safe and efficient operation, to track the maximum power from the PV solar cell arrays and to control the power which is injected from the inverter to the electrical grid.

PV-connected grid systems use good economic techniques to maximize the amount of power generated from PV arrays. These techniques, for achieving the above, are called the maximum power point tracking (MPPT). By these techniques, the output of a PV system, which matches with the grid for all atmospheric conditions, operates at maximum power point at all times.

The aim of this paper is to introduce a complete modeling, control and simulation of whole PV system connected to electrical grid through MATLABSIMULINK software.

\section{Mathematical modeling for the studied system}

Figure 1 shows the main building blocks of the studied system as described below:

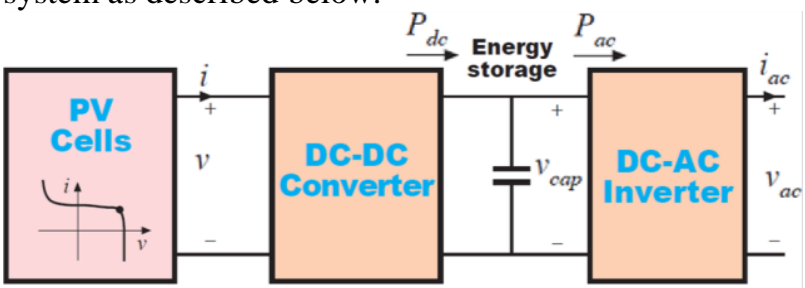

Fig.1 Main components of the studied system

The photovoltaic part or the PV array is the heart or the main source of energy in the system. It consists of a number of photovoltaic modules which collected to give suitable voltage source. In this system, the photovoltaic array consists of a ten modules in series and ten parallel strings. DC-DC conversion part is very necessary to obtain a suitable voltage source from PV source and implement MPPT technique. The DC-DC conversion part which used in this system is the booster. The inverter system is basically employed to convert the dc power, generated by the boost converter to three-or single phase ac power accepted by the conventional grid. This inverter, which is called solar inverter or PV inverter, converts the direct current/voltage (DC) output of a PV solar panel into a utility frequency alternating current/voltage (AC) that can be fed into a commercial electrical grid or used by a local off-grid electrical network. It is a critical component in a photovoltaic system allowing feeding AC loads.

\subsection{PV Model}

PV cell is basically a p-n junction fabricated in a thin wafer or layer of semiconductor. The electromagnetic radiation of solar energy can be directly converted to electricity through photovoltaic device. PV system normally introduces a nonlinear $\mathrm{I}-\mathrm{V}$ and $\mathrm{P}-\mathrm{V}$ characteristics which vary with the solar radiation and cell's surface temperature.

\subsubsection{Solar cell model}

A general mathematical description of $\mathrm{I}-\mathrm{V}$ output characteristics for a PV cell has been studied for over the past four decades [5]. The equivalent circuit of the general model which consists of a photo current, a diode, a parallel resistor expressing a leakage current, and a series resistor describing an internal resistance to the current flow, is shown in Fig 2.

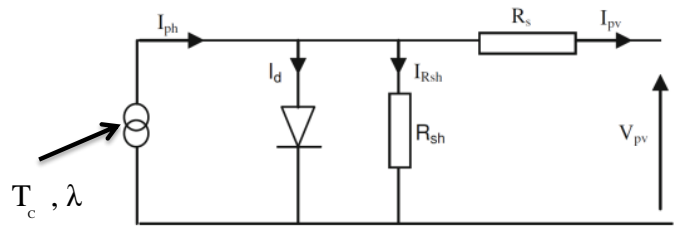

Fig. 2 The equivalent circuit of PV cell

The voltage-current characteristic equation of a solar cell is given as:

$I_{P V}=I_{P h}-I_{S}\left(e^{A\left(V+I \times R_{S}\right)}-1\right)-\frac{V+I_{P V} \times R_{S}}{R_{S h}}$

where, $\mathrm{I}_{\mathrm{Ph}}$ is a light-generated current or photocurrent, $I_{S}$ is the cell saturation of dark current, $q$ is an electron charge $\left(=1.6 \times 10^{-19} \mathrm{C}\right), \mathrm{k}$ is a Boltzmann's constant $\left(=1.38 \times 10^{-23} \mathrm{~J} / \mathrm{K}\right), \mathrm{T}_{\mathrm{C}}$ is the cell's working temperature, $A$ is an ideal factor, $R_{S h}$ is a shunt resistance, and $R_{S}$ is a series resistance. The photocurrent mainly depends on the solar irradiation and cell's working temperature, which is described as

$\mathrm{I}_{\mathrm{Ph}}=\left[\mathrm{I}_{\mathrm{SC}}+\mathrm{K}_{\mathrm{I}}\left(\mathrm{T}_{\mathrm{C}}-\mathrm{T}_{\mathrm{Ref}}\right)\right]\left[\lambda / \lambda_{\text {Ref }}\right]$

where, $\mathrm{I}_{\mathrm{SC}}$ is the cell's short-circuit current at a $25^{\circ} \mathrm{C}$ and $1 \mathrm{~kW} / \mathrm{m}^{2}, \mathrm{~K}_{\mathrm{I}}$ is the cell's short-circuit current temperature coefficient, $\mathrm{T}_{\mathrm{Ref}}$ is the cell's reference temperature, and $\lambda$ is the solar irradiation in $\mathrm{kW} / \mathrm{m}^{2}$. On the other hand, the cell's saturation current varies with the cell temperature, which is described as:

$I_{S}=I_{R S}\left(\frac{T_{C}}{T_{R e f}}\right)^{3} e^{\frac{\mathrm{qE}_{G}}{K a}\left(T_{R e f}{ }^{-1}-T_{C}^{-1}\right)}$

where, $I_{R S}$ is the cell's reverse saturation current at a reference temperature and a solar radiation $E_{G}$ is the bang-gap energy of the semiconductor used in the cell. The ideal factor A is dependent on PV technology [6].

\subsubsection{Solar module and array model}

Since a typical PV cell produces less than $2 \mathrm{~W}$ at $0.6 \mathrm{~V}$ approximately, the cells must be connected in series-parallel configuration on a module to produce enough high power. A PV array is a group of several PV modules which are electrically connected in series and parallel circuits to generate the required current and voltage. The terminal equation for the current and voltage of the array becomes as follows [6-9]:

$I_{P V}=I_{P h} N_{P}-I_{S} N_{P}\left(e^{\frac{A}{N_{S}}\left(V+I \times \frac{N_{S}}{N_{P}} \times R_{S}\right)}-1\right)-\frac{V+I_{P V} \times R s \times\left(N_{S} / N_{P}\right)}{R_{S h} \times\left(N_{S} / N_{P}\right)}$

where, $\mathrm{N}_{S}$ and $\mathrm{N}_{P}$ are series and parallel number of modules for a PV array respectively. 


\subsection{Modeling of the Booster and MPPT techniques 2.2.1. Modeling of the Booster}

Boost converter steps up the input voltage magnitude to a required output voltage magnitude without the use of a transformer. The main components of a boost converter as shown in fig. 3 are an inductor, a diode and a high frequency switch.

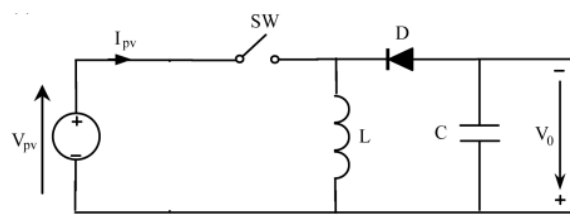

Fig. 3 The equivalent circuit of booster device

The co-ordinate manner supply power to the load at a voltage is greater than the input voltage magnitude. The control strategy lies in the manipulation of the duty cycle of the switch which causes the voltage change according to the following equation [10] and [11]:

$$
\mathrm{V}_{\mathrm{o}}=\frac{\mathrm{V}_{\text {in }}}{1-\mathrm{D}}
$$

where,

$$
\begin{aligned}
& \mathrm{V}_{\mathrm{in}}=\mathrm{V}_{\mathrm{PV}}=\mathrm{V}_{\mathrm{o}}+\mathrm{L} \frac{\mathrm{di}_{\mathrm{pv}}}{\mathrm{dt}}+\mathrm{i}_{\mathrm{pv}} \times \mathrm{R}_{\text {booster }} \\
& \mathrm{V}_{\mathrm{o}}=\frac{1}{\mathrm{c}} \int \mathrm{i}_{\mathrm{C}} \mathrm{dt} \\
& \mathrm{P}_{\mathrm{pv}}=\mathrm{P}_{\mathrm{o}}+\Delta \mathrm{P}_{\text {(Booster) }} \\
& \mathrm{P}_{\mathrm{o}}=\mathrm{P}_{\text {inv }}+\Delta \mathrm{P}_{\text {(Inverter) }}
\end{aligned}
$$

\subsubsection{Maximum Power Point Tracking Techniques}

\subsubsection{Incremental Conductance [INC] Technique}

In most maximum power point tracking techniques [MPPT] the varying of boost converter's duty cycle is a key for tracking process. At incremental conductance [INC] method, the array terminal voltage is always adjusted according to the maximum power point [MPP] voltage and it is based on the incremental and instantaneous conductance of the PV module.

Figure 4 shows that the slope of the P-V array power curve is zero at the maximum power point [MPP], increasing on the left of the MPP and decreasing on the Right hand side of the MPP. The basic equations of this method are as follows:

$$
\begin{array}{ll}
\frac{\mathrm{dI}}{\mathrm{dV}}=-\frac{\mathrm{I}}{\mathrm{V}} & \text { At MPP } \\
\frac{\mathrm{dI}}{\mathrm{dV}}>-\frac{\mathrm{I}}{\mathrm{V}} & \text { Left of MPP } \\
\frac{\mathrm{dI}}{\mathrm{dV}}<-\frac{\mathrm{I}}{\mathrm{V}} & \text { Right of MPP }
\end{array}
$$

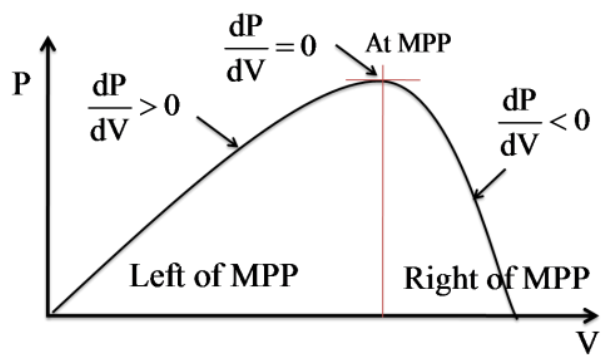

Fig. 4 The INC tracking method

where, I and V are PV array's output current and voltage, respectively. The left hand side of the previous equations represents incremental conductance of PV module and the right hand side represents the instantaneous conductance. When the ratio of change in output conductance is equal to the negative output conductance, the solar array will operate at the maximum power point. The MPPT regulates the duty cycle of the DC-DC boost converter until the condition: $(\partial \mathrm{I} / \partial \mathrm{V})+$ $(\mathrm{I} / \mathrm{V})=0$ is satisfied. In this method, the peak power of the module lies at above $98 \%$ of its incremental conductance. The Flow chart of incremental conductance MPPT is shown in Fig 5.

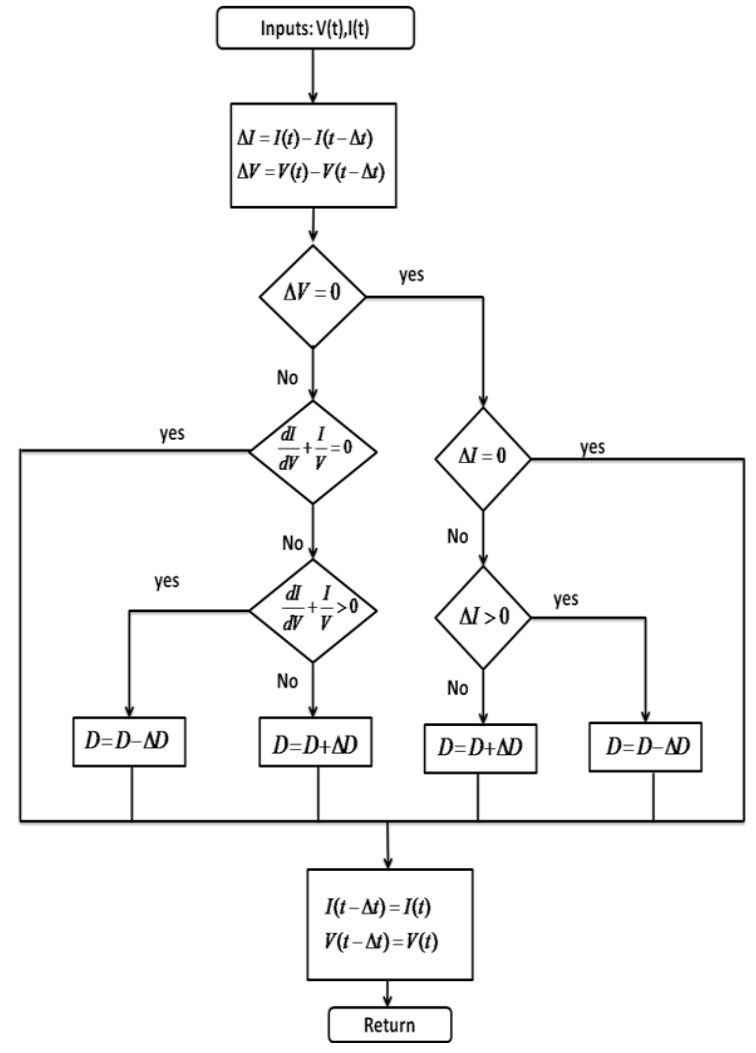

Fig. 5 INC MPPT Flow chart 


\subsubsection{Fuzzy Logic System for MPPT technique}

Figure 6 shows the fuzzy system in MATLABSIMULINK which used instead of INC MPPT method.

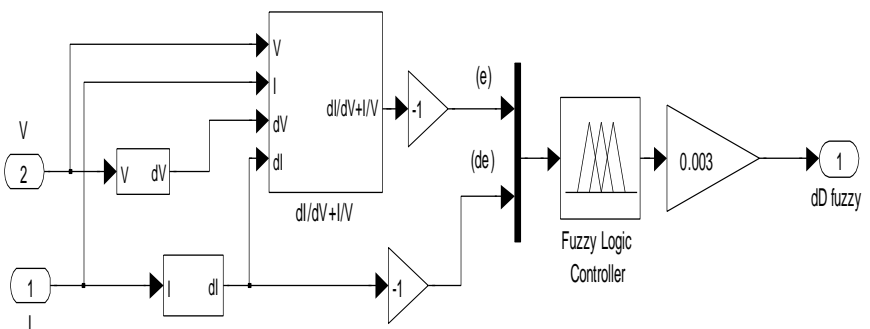

Fig. 6 MATLAB-SIMULINK for fuzzy logic of MPPT

\section{* Fuzzification}

Usually, a large number of membership functions are defined, such as negative-big, negative-medium, negative-small, etc. This is not necessary, and it introduces an additional complexity to the controller tuning, as the boundaries between seven or more membership functions have to be defined, for each variable. In this case, a set of three membership functions is chosen: negative (NE) positive $(\mathrm{P})$ and zero (ZE). The partition of fuzzy subsets and the shape of membership function, which can adapt shape up to appropriate system, are shown in Fig 7. The value of input error (e) and change of error (de) are normalized by an input scaling factor. In this system, the input scaling factor is designed such that input values are between -8 and 8 . This reduces tuning complexity.

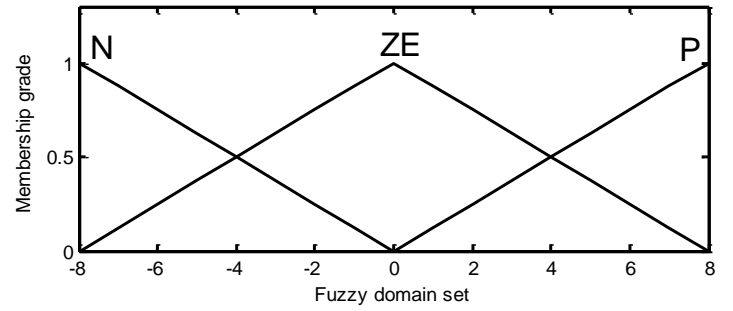

Fig.7. Membership function for inputs (e and de)

* Inference method

Table 1 shows rule base of the FLC. For this system, Sugeno-style Inference is selected.

Table 1 Rule base of fuzzy logic system

\begin{tabular}{|c|c|c|c|}
\hline de e & $N$ & ZE & P \\
\hline$N$ & $N$ & $Z E$ & $N$ \\
\hline$Z E$ & $N$ & $Z E$ & $P$ \\
\hline$P$ & $Z E$ & $P$ & $P$ \\
\hline
\end{tabular}

\section{* Defuzzification}

A defuzzification stage is needed to produce a nonfuzzy output. Defuzzificaion for this system is weighted average method which is both simple and fast.

\subsubsection{Simulation Results}

The difference between INC MPPT method performance and Fuzzy MPPT method performance is shown through figures $8-10$.
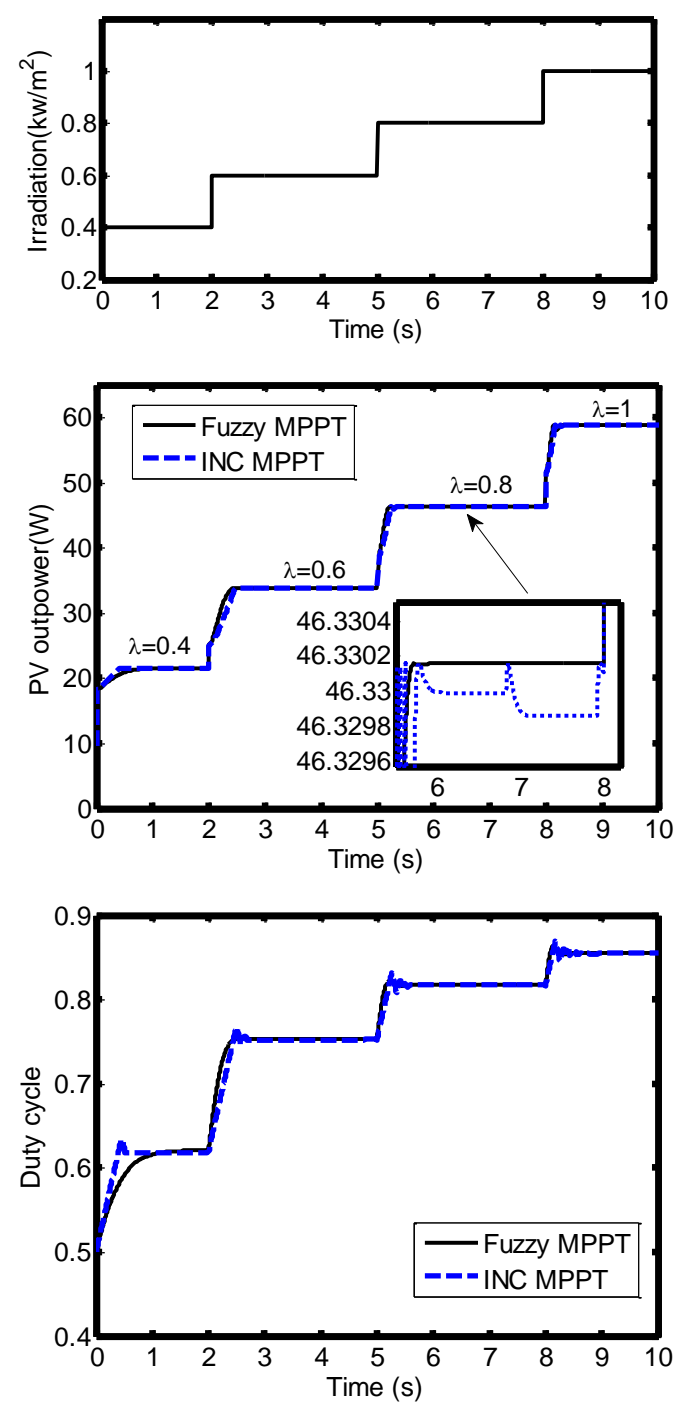

Fig. 8 MPPT results with irradiation varying from 0.4 to 1 by a step of 0.2
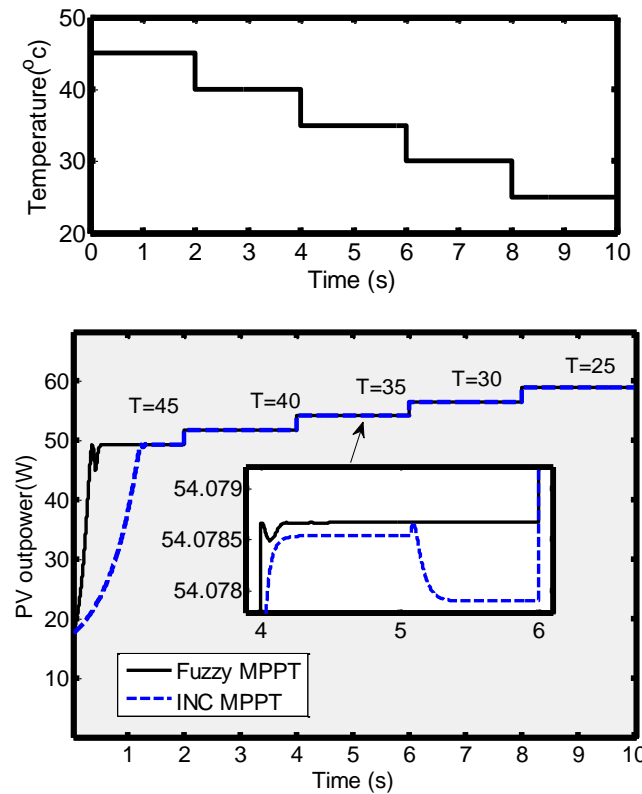


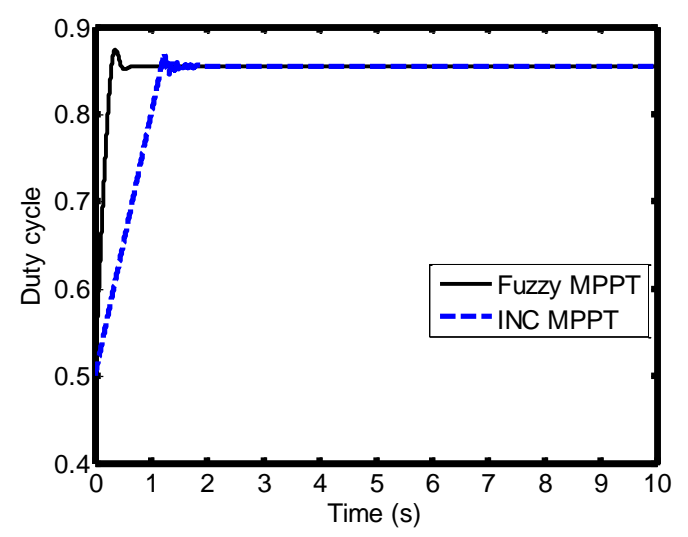

Fig. 9 MPPT results with a temperature decreasing from $45^{\circ} \mathrm{c}$ to $25^{\circ} \mathrm{c}$ by a step of 5
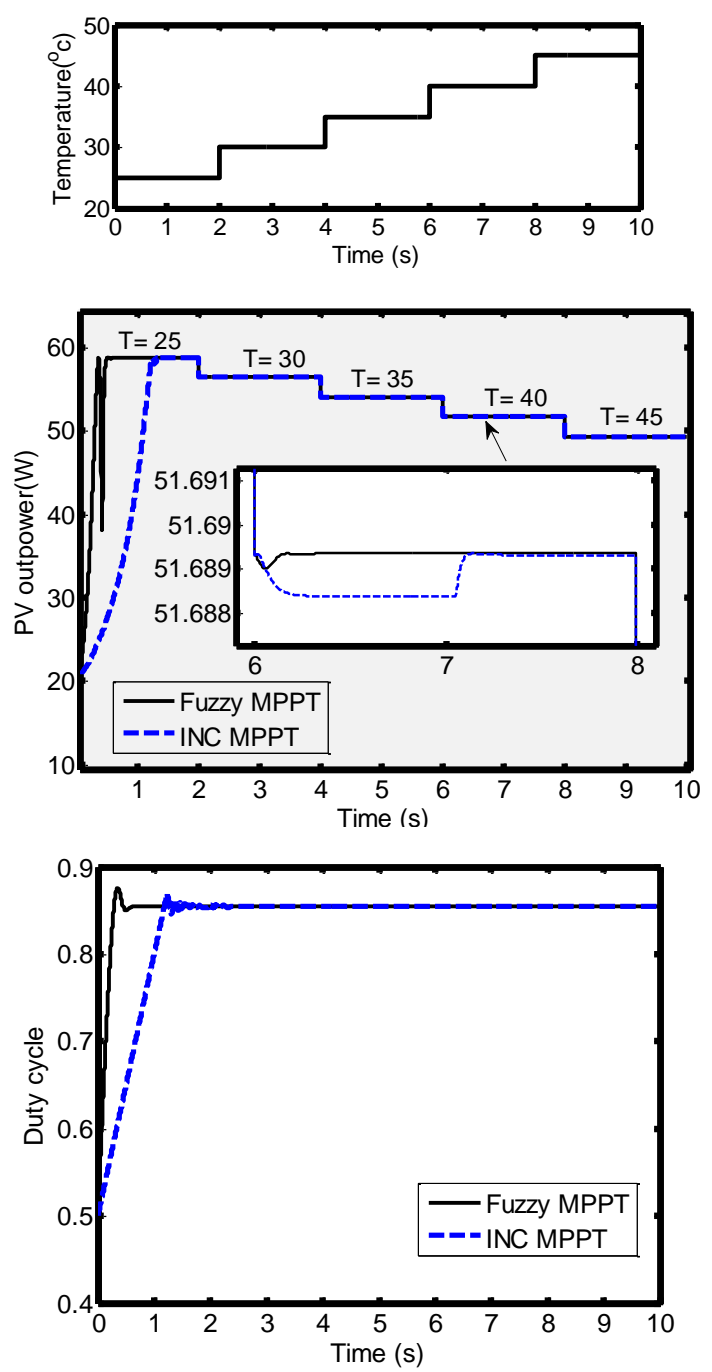

Fig. 10 MPPT results with a temperature increasing from $25^{\circ} \mathrm{c}$ to $45^{\circ} \mathrm{c}$ by a step of 5

\subsection{Inverter Modeling and control system}

\subsubsection{Inverter Modeling}

In the case of grid-connected PV system, different inverter topologies and controllers are usually used for interfacing the PV array and the utility grid [12-14]. Two inverter configurations and three inverter topologies can be identified in such applications, namely: central inverter, string inverter and integrated inverter for configuration; and topologies with or without transformer [12].

The converter proposed in this field is a three-phase bidirectional DC-AC converter with PWM modulation using six power switches. The bi-directional characteristic of the converter is very important in this proposed photovoltaic system, because it allows the processing of active and reactive power from the generator to the load and vice versa, depending on the application. Thus, with an appropriate control of the power switches, it is possible to control the active and reactive power flow.

Figure 11 shows the schematic of the inverter, in which a dc-link capacitor is on the left, and a threephase voltage source of the utility grid, representing the voltage at output side from inverter, is on the right

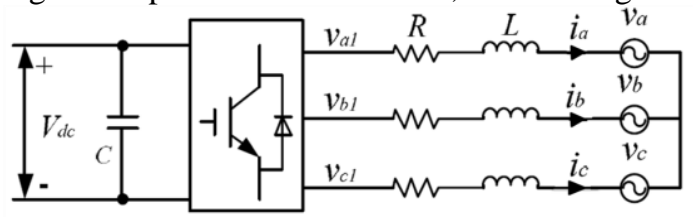

Fig. 11 Inverter converter schematic

From the fig. 11, the following dynamic equation can be obtained:

$$
\left[\begin{array}{l}
v_{a} \\
v_{b} \\
v_{c}
\end{array}\right]=R\left[\begin{array}{l}
i_{a} \\
i_{b} \\
i_{c}
\end{array}\right]+L \frac{d}{d t}\left[\begin{array}{c}
i_{a} \\
i_{b} \\
i_{c}
\end{array}\right]+\left[\begin{array}{c}
v_{g a} \\
v_{g b} \\
v_{g c}
\end{array}\right]
$$

The currents flowing between the inverter and the grid are obtained according to the next equations:

$I_{d}=\int \frac{1}{L}\left(V_{d}-R I_{d}+L \omega_{s} I_{q}-V_{g q}\right)$
$I_{q}=\int \frac{1}{L}\left(V_{q}-R I_{q}-L \omega_{s} I_{d}-V_{g q}\right)$

The output instantaneous active and reactive powers from inverter are proportional to the line's d- and q-axis currents, respectively, as:

$$
\begin{aligned}
& \mathrm{P}(\mathrm{t})=\mathrm{v}_{\mathrm{d}} \mathrm{i}_{\mathrm{d}}+\mathrm{v}_{\mathrm{q}} \mathrm{i}_{\mathrm{q}}=\operatorname{real}\left(\mathrm{VI}^{*}\right) \\
& \mathrm{Q}(\mathrm{t})=\mathrm{v}_{\mathrm{q}} \mathrm{i}_{\mathrm{d}}-\mathrm{v}_{\mathrm{d}} \mathrm{i}_{\mathrm{q}}=\operatorname{imagine}\left(\mathrm{VI}^{*}\right)
\end{aligned}
$$




\subsubsection{Control of Three Phase Grid Connected PV System}

In this paper PI and fuzzy logic control methods are implemented through MATLAB for the system.

\subsubsection{PI Control}

The control approach in designing the grid connected PV system, as a shown in Fig 12, employs three control loops: The first control loop, called booster control shown in Fig 13, is used to keep the magnitude of the DC link voltage constant and to control the duty cycle for MPPT achievement. The second control loop is used to regulate the magnitude of the inverter output voltage at a suitable value for regulation standard under various disturbances. The third control loop is used to keep the inverter output reactive power at small value $(\mathrm{Q} \approx 0)$ or (unity power factor operation) to keep the current in phase with voltage. Fig. 14 shows Voltage Regulation and unity power factor control structure. This power system is simulated using MATLAB-SIMULINK environment and is tested under various disturbances. By Figs 13-14 and the existing parameter in Table 2, the PI control can be implemented.

Table 2 PI controller parameters.

\begin{tabular}{|l|l|l|l|}
\hline Parameter & $\begin{array}{l}\text { Booster } \\
\text { Control }\end{array}$ & $\begin{array}{l}\text { Voltage } \\
\text { Regulation } \\
\text { Control }\end{array}$ & $\begin{array}{l}\text { Unity P.F } \\
\text { Control }\end{array}$ \\
\hline $\mathrm{K}_{\mathrm{p}}$ & 0.0482 & 0.00223 & 0.00223 \\
\hline $\mathrm{K}_{\mathrm{i}}$ & 1.05261 & 0.00831 & 0.00831 \\
\hline
\end{tabular}

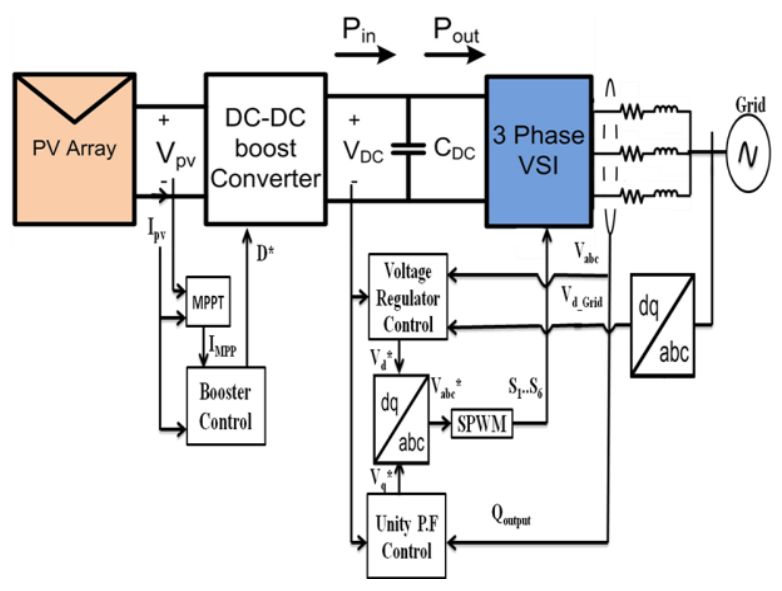

Fig. 12 PV grid connected block diagram overview

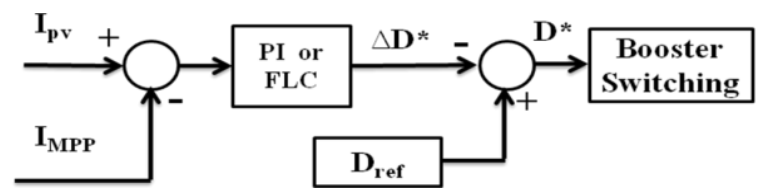

Fig. 13 Booster control structure

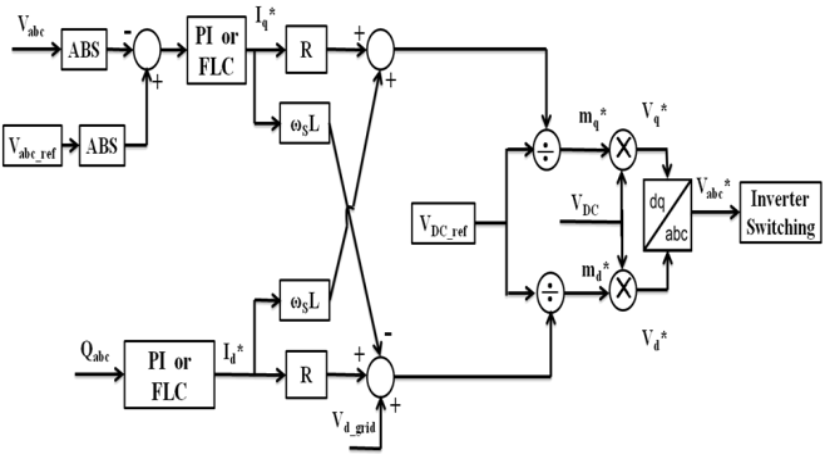

Fig. 14 Voltage Regulation and unity P.F control

\subsubsection{Fuzzy Logic Control System}

In this section, fuzzy controllers are implemented through MATLAB instead of PI controllers for the system as shown in Fig 15.

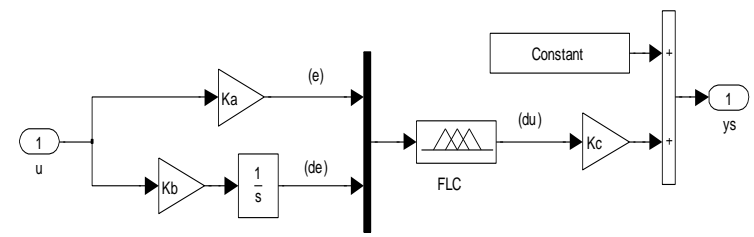

Fig.15 MATLAB-SIMULINK for fuzzy logic controller

The Values of $\mathrm{Ka}, \mathrm{Kb}, \mathrm{Kc}$ and the constant value are shown in Table 3 where these values are changed depending on controller loop.

Table 3 Fuzzy controller parameters.

\begin{tabular}{|l|l|l|l|l|}
\hline Controller & Ka & Kb & Kc & Constant Value \\
\hline Booster Control & 1 & 1.5 & 10 & Zero \\
\hline Voltage Regulation & $\mathbf{0 . 0 0 5}$ & $\mathbf{0 . 0 1 3 3 4}$ & 1 & Initial of Iq \\
\hline P.F control & $3.334 \mathrm{e}-5$ & $\mathbf{0 . 0 0 0 2}$ & $\mathbf{9 0}$ & Initial of Id \\
\hline
\end{tabular}

* Fuzzification

In this case, the membership function has the same shape shown before in Fig 7. But the value of input error (e) and change of error (de) are normalized by an input scaling factor designed between -1 and 1 .

* Inference method

Table 4 shows rule base of the FLC. For this system, Sugeno-style Inference is selected.

Table 4 Rule base of fuzzy logic controller

\begin{tabular}{|c|c|c|c|}
\hline de & $N$ & $Z E$ & $P$ \\
\hline$N$ & $N$ & $Z E$ & $P$ \\
\hline$Z E$ & $Z E$ & $Z E$ & $P$ \\
\hline$P$ & $P$ & $Z E$ & $P$ \\
\hline
\end{tabular}

\section{* Defuzzification}

Defuzzificaion for this system is weighted average method which is both simple and fast. 


\subsubsection{Simulation Results}

The system simulation results are obtained when the system runs using the fuzzy logic control (FLC) at different disturbances and the results are compared with PI controllers at the same disturbances. Every result runs at a complete control (booster and inverter controls) including fuzzy MPPT procedure. The system response is represented in form of: output voltage, output active and reactive powers at inverter terminals, PV output power and DC link voltage. Figures 16-18 show the response when the system is subjected to different disturbances such as one line outage, 3-phase short circuit close to the infinite bus and when irradiation disturbance at various levels, respectively.
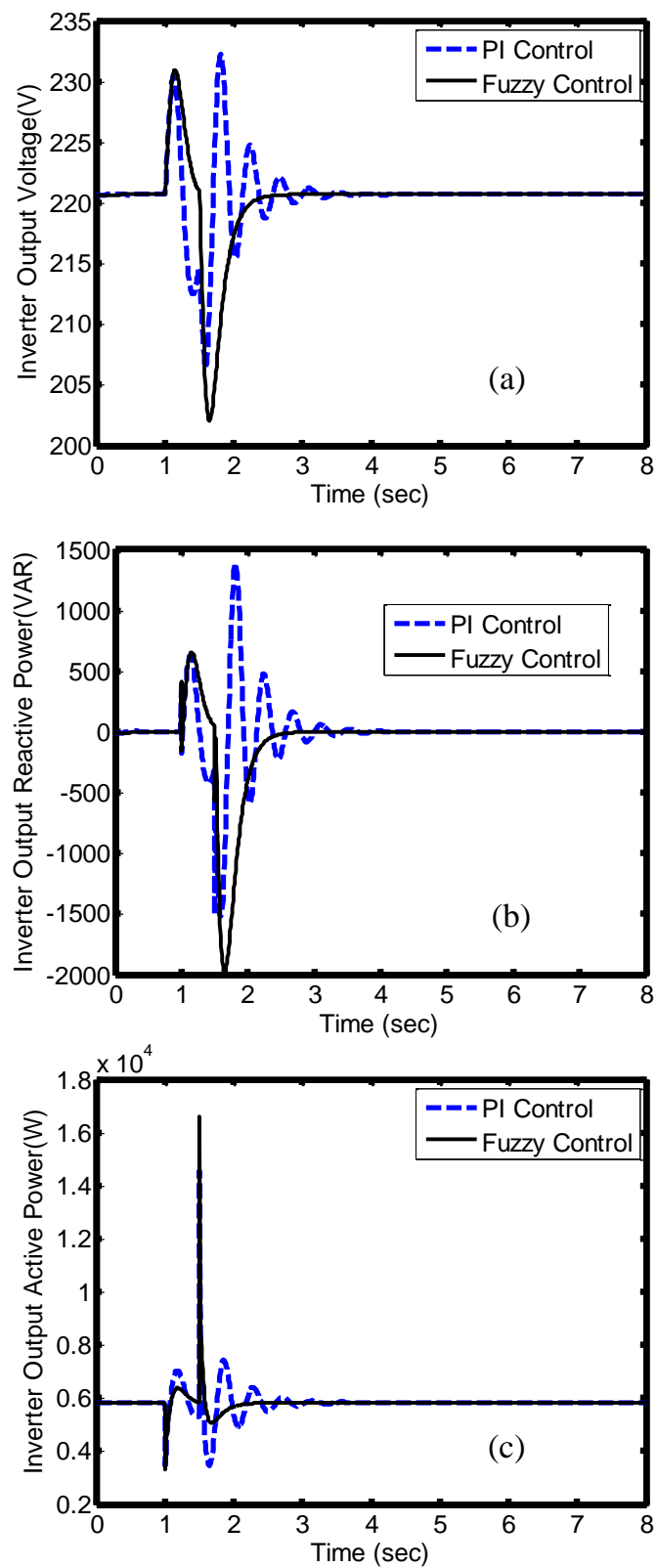
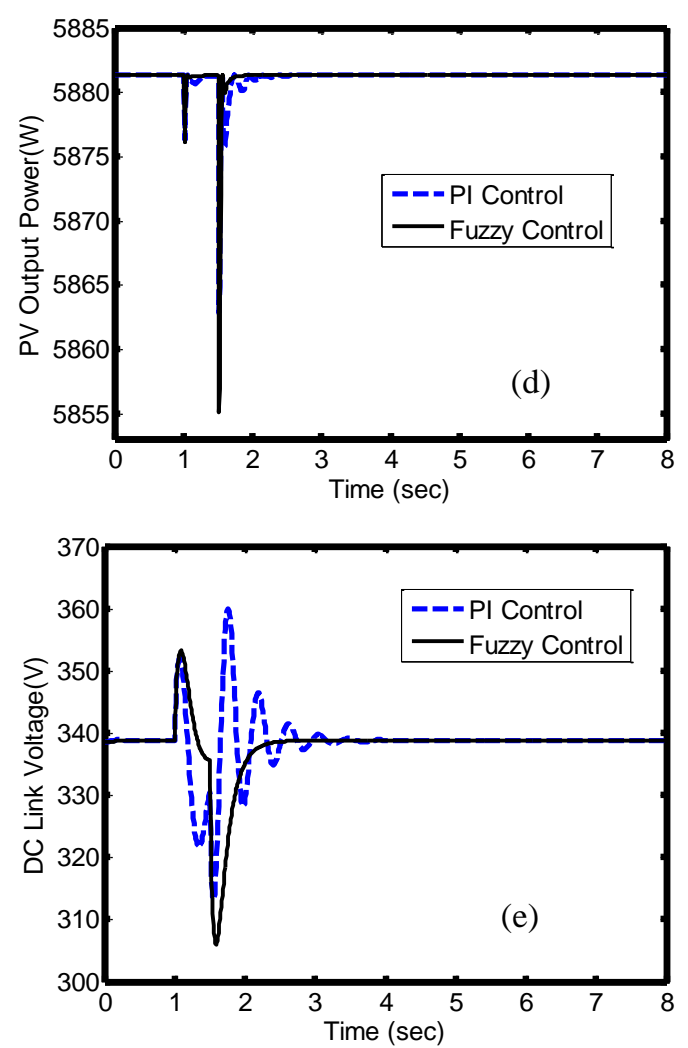

Fig. 16 System response to one line outage fault for 0.5 $\sec$
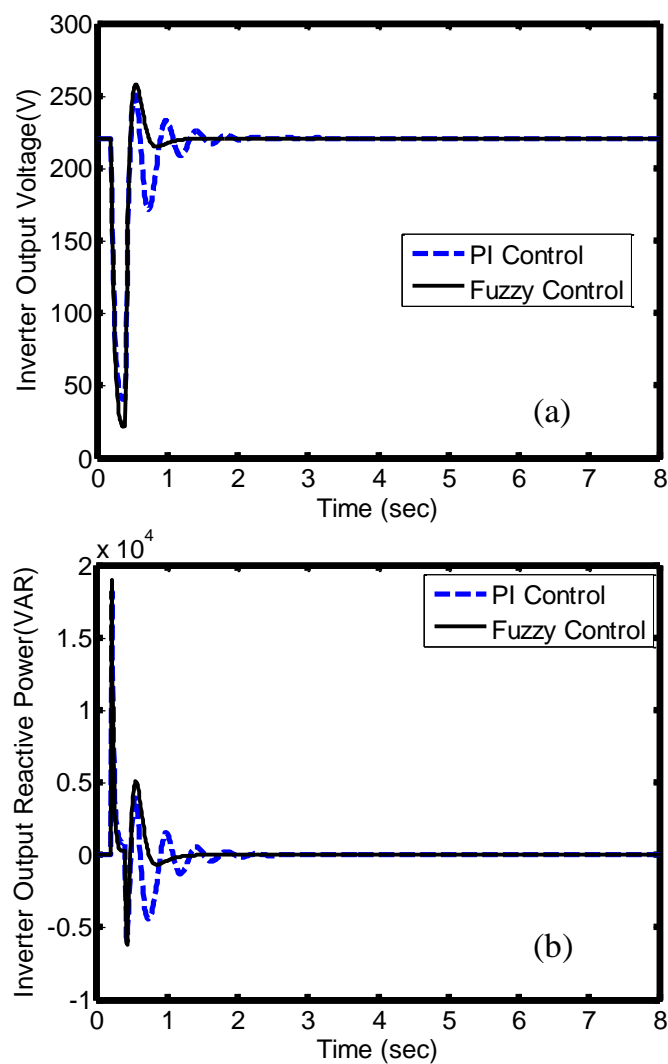

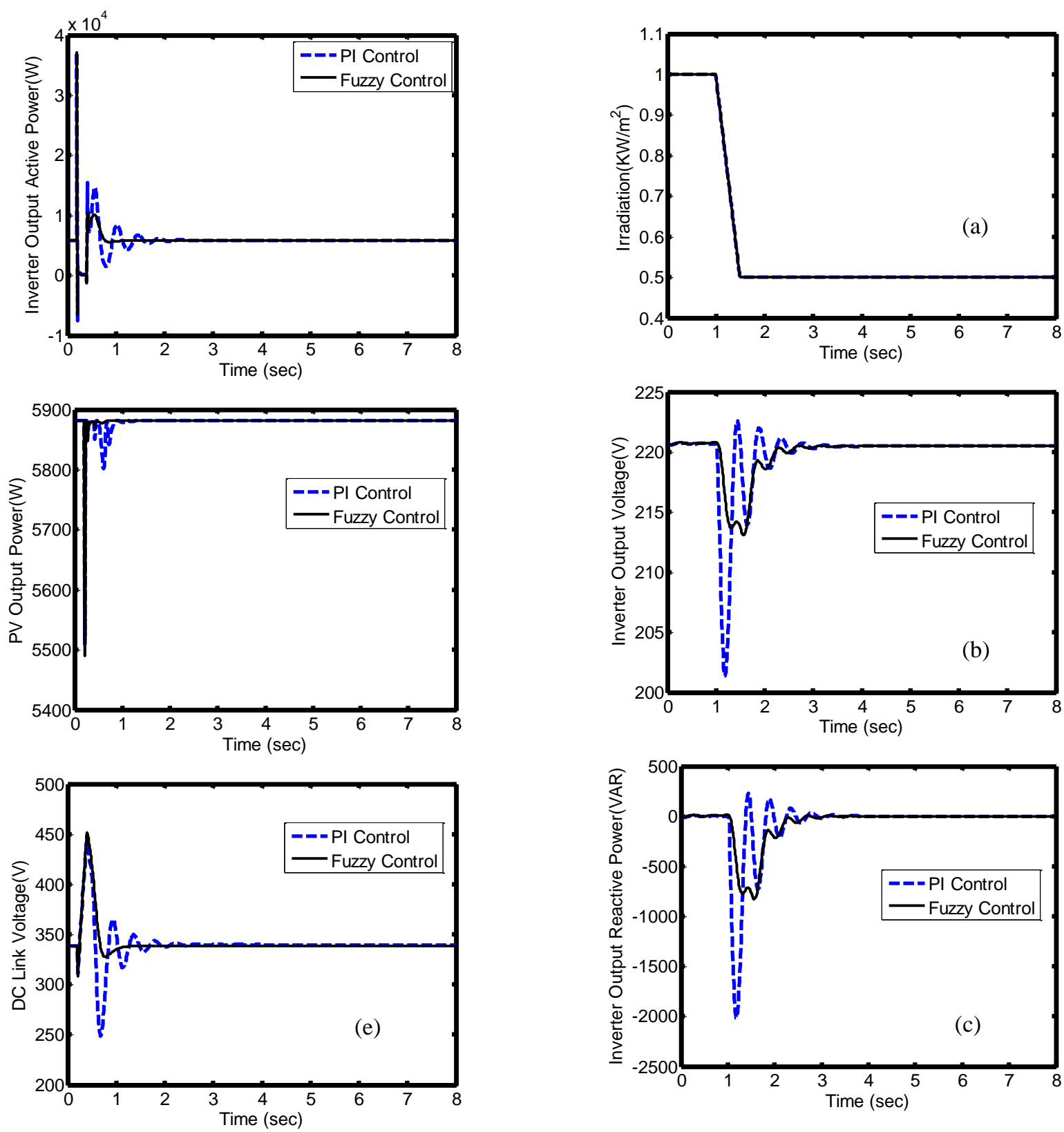

Fig.17 System transient response to a 3-phase short circuit for $200 \mathrm{~ms}$.

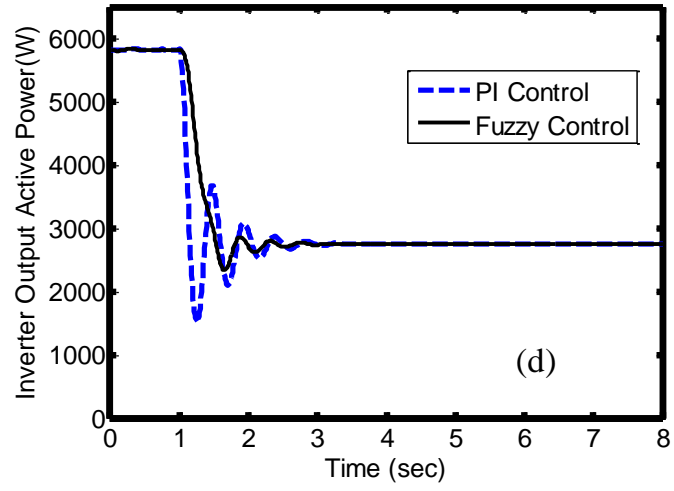



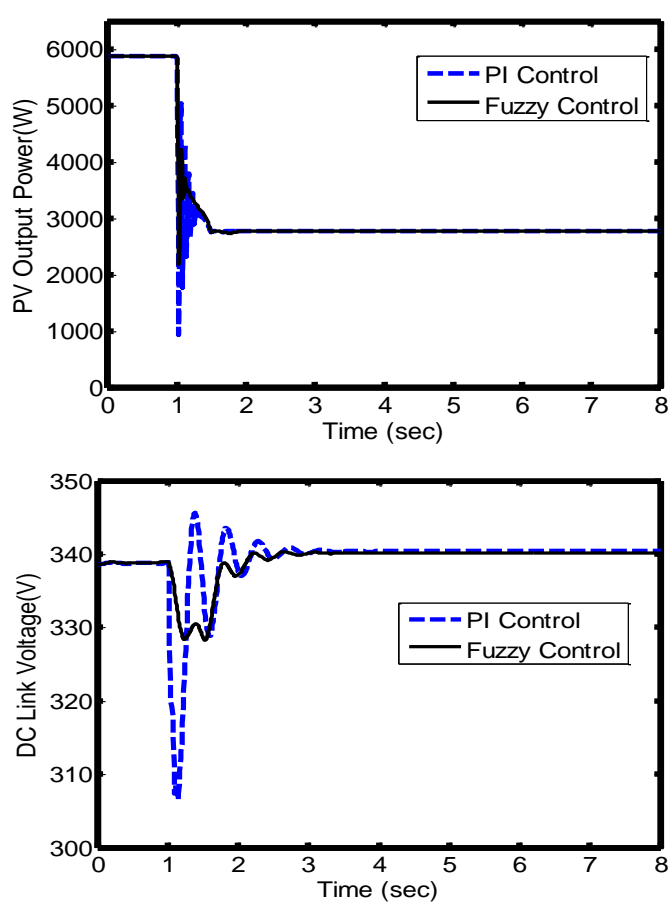

Fig. 18 System response to irradiation disturbance $\left(1 \mathrm{~kW} / \mathrm{m}^{2}\right.$ to $\left.0.5 \mathrm{~kW} / \mathrm{m}^{2}\right)$ after $1 \mathrm{sec}$

\section{Conclusion}

In this paper modeling, control and simulation of PV arrays connected to electrical grid is introduced. The system is simulated under MATLAB-SIMULINK environment using various control systems. The system is controlled using PI and FL controllers in addition to implementation MPPT algorithms (by INC and FL). In view of weather conditions variations, the system response using fuzzy MPPT method is better than using INC MPPT technique in terms of small rise time, small settling time and small steady state error. For grid faults, By FLC technique, the system is more stable speedily and softly at desired value with less oscillations compared with PI control system. Also, from these results it is concluded that the system response using FLC is better than using PI control in terms of small amplitude of the first swing (damping increase), small settling time under various disturbances.

\section{REFERENCES}

[1] S. R. Bull, "Renewable energy today and tomorrow", Proc. IEEE, Vol. 89, No. 8, pp. 12161226, Aug. 2001.

[2] S. Rahman, "Green power: What is it and where can we find it?", IEEE Power Energy Mag., Vol. 1, No. 1, pp. 30-37, Jan. 2003.

[3] J. A. Gow and C. D. Manning, "Photovoltaic converter system suitable for use in small scale stand-alone or grid connected applications", Proc. IEE Electr. Power Appl., Vol. 147, No. 6, pp. 535543, June 2000.

[4] T. Shimizu, O. Hashimoto, and G. Kimura, "A Novel high performance utility-interactive photovoltaic inverter system", IEEE Trans. Power Electron., Vol. 18, No. 2, pp. 704-711, Feb. 2003.

[5] T. F. Wu, C. H. Chang and Y. K. Chen, "A multiFunction photovoltaic power supply system with grid connection and power factor correction features", IEEE 31st Annual conference on power electronics specialists PESC'2000, Vol. 3, pp. 1185-1190, 2000.

[6] J. A. Gow and C. D. Manning, "Development of a photovoltaic array model for use in powerelectronics simulation studies", IEE ProceedingsElectric Power Applications, Vol. 146, No. 2, pp. 193-199, 1999.

[7] M. Veerachary, T. Senjyu, and K. Uezato, "Voltage-based maximum power point tracking control of PV system", IEEE Transactions on Aerospace and Electronic Systems, Vol. 38, No. 1, pp. 262-270, 2002.

[8] I. S. Kim and M. J. Youn, "Variable-structure observer for solar array current estimation in a photovoltaic power-generation system", IEE Proceedings-Electric Power Applications, Vol. 152, No. 4, pp.953-959, 2005.

[9] A. R Reisi, M H Moradi and S Jamsab, "Classification and comparison of maximum power point tracking techniques for photovoltaic system", A review Renewable and Sustainable Energy Reviews, vol. 19, pp. 433-443, 2013

[10] A. K. Verma, B. Singh and S.C Kaushik, " An Isolated Solar Power Generation using Boost Converter and Boost Inverter", in Proc. National Conference on Recent Advances in Computational Technique in Electrical Engineering, SLITE, Longowal (India), paper 3011, pp.1-8, 19-20 March, 2010.

[11] A. Kalirasu and S. S. Dash, "Simulation of Closed Loop Controlled Boost Converter for Solar Installation", Serbian Journal of Electrical Engineering, Vol. 7, No. 1, pp. 121-130, May 2010.

[12] M. Calais, J. M. A. Myrzik, T. Spooner and V.G. Agelids, "Inverters for single-phase grid connected photovoltaic system-an overview", IEEE 33rd Annual power electronics specialist's conference, Vol. 4, pp. 1995-2000, 2002.

[13] N. E. Shtawa, M. R. Abuzeid and L. M. Daloub, "Stand-Alone PV System Using Adaptive Control", Jounal of Automation and Control Engineering, Vol. 2, No. 4, pp. 406-409, December, 2014.

[14] N. G. M. Thao and K. Uchida, "A Control Strategy based on Fuzzy Logic for Three-phase Gridconnected Photovoltaic System with Supporting Grid-frequency Regulation", Jounal of Automation and Control Engineering, Vol. 4, No. 2, pp. 96103, April, 2016. 
R.A.Amer, A.M.Afifi and G.A.Morsy " A NOVEL FLC FOR PV ARRAYS CONNECTED TO THE ..." 